\title{
Ultrasonographic detection of nuchal cord: required or not
}

\author{
Vijayata Sangwan*, Mukesh Sangwan, Sunita Siwach, \\ Rajiv Mahendroo, Richa Kansal, Pinki Lakra
}

\begin{abstract}
Department of Obstetrics \& Gynecology, B.P.S. Government Medical College for Women Khanpur Kalan, Sonepat131305, Haryana, India
\end{abstract}

Received: 24 May 2014

Accepted: 10 June 2014

\author{
*Correspondence: \\ Dr. Vijayata Sangwan, \\ E-mail: vsangwan03@gmail.com
}

(C) 2014 Sangwan V et al. This is an open-access article distributed under the terms of the Creative Commons Attribution Non-Commercial License, which permits unrestricted non-commercial use, distribution, and reproduction in any medium, provided the original work is properly cited.

\begin{abstract}
Background: Nuchal cord is defined as an umbilical cord that passes 360 around the neck. From a long time nuchal cord is considered as one of the cause for birth asphyxia and neonatal complications. For ultraonographic detection of nuchal cord and use of colour Doppler for the same is emphasized a lot in literature. On the other side studies are there that don't support the ultrasonographic detection of nuchal cord. Practically also on one sides it makes the attendants more anxious and results in unnecessary caesarean section as well as results in malpractice also. This study was conducted to assess the requirement of nuchal cord detection at any phase of gestation.

Methods: This is a retrospective study conducted in the department of obstetrics \& gynecology in a rural tertiary health care centre in one year duration. All the patients having nuchal cord at the time of delivery or caesarean section were included in the study. The case reports were anslysed retrospectively for neonatal outcome and progress of labour.

Results: The incidence of nuchal cord was $6.63 \%$, irrespective of number of loops. The incidence of single loop was $5.32 \%$ double loop was $1.14 \%$ three loop was $0.17 \%$. One patient had four loops of cord around neck and one patient had true knot in the cord but neonatal outcome was absolutely normal in both patients. The profile of patients was discussed in Table 1. A total of $85 \%$ patients were less than 30 year age group with literacy level of $65 \%$ and $55 \%$ patients were primigravida.20 patients developed prolonged labour, 13 patients among these responded to oxytocin and delivered normally and rest 07 underwent lower segment caesarean section for non-progress of labour or fetal distress. The duration of labour was found prolonged in patients $\mathrm{w}$ and triple nuchal cords. $53(27.60 \%)$ fetus had unfavourable APGAR at birth, among these 20 had single tight loop of cord around neck, recovered soon as the cord was clamped and cut. Among rest 33 fetus 03 had three loops of cord around neck, 07 had two tight loops of cord around neck, in rest 23 fetus loops of cord were present besides that other factors like prematurity (11), severe preeclampsia (06), chorioamnionits (02), antepartum hemorrhage (04) were also present, may be responsible for fetal distress.

Conclusions: Routine ultrasonographic nuchal cord detection is not required and should not alter obstetric management of the patient.
\end{abstract}

Keywords: Nuchal cord, Ultrasonographic, Doppler

\section{INTRODUCTION}

Nuchal cord is defined as an umbilical cord that passes 360 around the neck. ${ }^{1}$ It has been referred to as "one of the dangers of eighth month" by Hippocrates. " The prevalence at delivery has been reported as being between $6 \%$ and $37 \%$. The nuchal may be single, double, triple, however there are a case reports describing a cord looped as many as nine times around the neck. ${ }^{1}$ Review of literature suggests an association of a nuchal cord with 
an increased risk of adverse pregnancy outcomes. These include meconium stained amniotic fluid, low 5 minute APGAR scores, an increased rate of caesarean deliveries, fetal heart rate decelerations, umbilical artery acidemia and even fetal death. ${ }^{3}$ The role of sonography in prenatal diagnoses of nuchal cord has been validated in many previous publications and use of colour Doppler flow has increased the accuracy of this prenatal diagnosis. ${ }^{2}$ As now a days ultrasonography is a routinely done procedure and ultrasonologists, obstetricians and more importantly parents directly face the diagnosis. This subjects parents as well as obstetricians to high levels of anxiety especially during the period of labour and many a times results in unnecessary caesarean section. ${ }^{1}$ In the peripheral areas this has also become an indication of caesarean deliveries results in malpractice. We tried to assess the effects of nuchal cord on neonatal outcome and duration of labour by this study.

\section{Aim \& objectives}

The aim of this study was to assess the requirement of nuchal cord detection on sonography. The objectives to achieve the aim were the assessment of effect of nuchal cord on neonatal outcome and on the duration of labour.

\section{METHODS}

This is a retrospective study conducted in the department of obstetrics \& gynecology in Bhagat Phool Singh govt. medical college for women Khanpur Kalan, Sonepat, Haryana in one year duration i.e. form $1^{\text {st }}$ January 2013 to $31^{\text {st }}$ December 2013. Records were obtained from the medical record department and analysed for material and fetal outcome.

\section{Inclusion criteria}

1. All the patients who had nuchal cord at the time of delivery irrespective of number of loops of cord.

2. All the caesarean section done where nuchal cord was intraoperative finding irrespective of the indication of caesarean section.

3. Other factors like preeclampsia, IUGR, anaemia, malpresentations were also assessed while analysing the neonatal outcome as these factors has a chronic effect on fetus while nuchal cord mainly produces acute effect on fetus by its compression effect thus decreasing blood supply to the fetus as head descends down.

Nuchal cord termed as loose when it could be slipped over the head easily and tight when it had to be clamped and cut before delivering the fetus. ${ }^{4}$ The induction and augmentation of labour by artificial rupture of membranes and oxytocin was done according standard guidelines. The fetal heart rate monitoring was done by auscultatory method as per guidelines. The duration of labour was calculated once the patient entered in active phase as defined above.

\section{RESULTS}

Ours is a government tertiary care started on $1^{\text {st }}$ September 2011 in the heart of rural Haryana and now acts as a referral centre in $80-100 \mathrm{~km}$. radius. In year 2013, 2753 vaginal deliveries and 369 caesarean deliveries were conducted in our department and nuchal cord was detected in 192 patients including vaginal and abdominal deliveries. The incidence of nuchal cord was $6.63 \%$, irrespective of number of loops. The incidence of single loop was $5.32 \%$ double loop was $1.14 \%$ three loop was $0.17 \%$. One patient had four loops of cord around neck and one patient had true knot in the cord but neonatal outcome was absolutely normal in both patients. The profile of patients is discussed in Table 1. A total of $85 \%$ patients were less than 30 year age group with literacy level of $65 \%$ and $55 \%$ patients were primigravida.

Table 1: Patients profile.

\begin{tabular}{|c|c|c|}
\hline & $\begin{array}{l}\text { No. of } \\
\text { patients }\end{array}$ & $\begin{array}{l}\% \text { of } \\
\text { patients }\end{array}$ \\
\hline \multicolumn{3}{|c|}{ Age group of patients } \\
\hline$>20$ year & 24 & 12.50 \\
\hline 21-30 year & 140 & 72.91 \\
\hline$>30$ year & 28 & 14.58 \\
\hline \multicolumn{3}{|c|}{ Literacy status of patients } \\
\hline literate & 124 & 64.58 \\
\hline Illiterate & 68 & 35.41 \\
\hline \multicolumn{3}{|l|}{ Parity of patients } \\
\hline Primiparous & 106 & 55.20 \\
\hline Multiparous & 77 & 40.10 \\
\hline Grand multiparous & 09 & 04.68 \\
\hline
\end{tabular}

Table 2, depicts the stage of labour at the time of admission and approximately $54 \%$ patients were admitted in active stage of labour. Among these 18 (09.37\%) patients admitted for induction of labour, $09(50 \%)$ patients were induced for postdatism, 07(39\%) patients for leaking per vaginum for more than 12 hours, 02 (11\%) patients for severe preeclampsia. 15 patients reported in advanced stage of labour and $13(86.66 \%)$ among them taken directly on labour table for delivery.

Table 2: Stage of labour at the time of admission.

\begin{tabular}{|lll|}
\hline Stage of labour & $\begin{array}{l}\text { No. of } \\
\text { patients }\end{array}$ & $\begin{array}{l}\% \text { of } \\
\text { patients }\end{array}$ \\
\hline Induction of labour & 18 & 09.37 \\
\hline Latent stage & 71 & 36.97 \\
\hline Active stage & 88 & 45.88 \\
\hline Advanced stage & 15 & 07.82 \\
\hline
\end{tabular}

Among 192 only 174 patients entered in active phase of labour. In the rest 18 patients 08 patients were of failed induction, 06 patients were previous two lower segment caesarean section, 03 patients had malpresentation and 
one patient had transverse lie with placenta previa, were taken for caesarean section.

Among these 174 patients, 20 patients developed prolonged labour, 13 patients among these responded to oxytocin and delivered normally and rest 07 underwent lower segment caesarean section for non-progress of labour or fetal distress. The duration of labour was found prolonged in patients with double and triple nuchal cords as shown in Table.

Table 3: Patients classified according to duration of labour.

\begin{tabular}{|lllll|}
\hline $\begin{array}{l}\text { Duration } \\
\text { of labour } \\
\text { (hour) }\end{array}$ & $\begin{array}{l}\text { Total } \\
\text { No. of } \\
\text { patients }\end{array}$ & $\begin{array}{l}\text { Patients } \\
\text { with single } \\
\text { loop of } \\
\text { cord }\end{array}$ & $\begin{array}{l}\text { Patients } \\
\text { with two } \\
\text { loop of } \\
\text { cord }\end{array}$ & $\begin{array}{l}\text { Patients } \\
\text { with } \\
\text { three loop } \\
\text { of cord }\end{array}$ \\
\cline { 1 - 3 } $\begin{array}{l}\text { Less than } \\
\text { one hour }\end{array}$ & 32 & 26 & 06 & 00 \\
\hline 1-5 hour & 58 & 49 & 09 & 00 \\
\hline 6-10 hour & 64 & 58 & 04 & 02 \\
\hline$>10$ hour & 20 & 06 & 12 & 02 \\
\hline
\end{tabular}

On analysis of mode of delivery 147 (76.56\%) delivered vaginally, $15(7.81 \%)$ had instrumental delivery and 30 $(15.62 \%)$ underwent lower segment caesarean section. Table 4 demonstrates it with indication.

Table 4: Mode of delivery with indication.

\begin{tabular}{|c|c|c|}
\hline Mode of delivery with indication & $\begin{array}{l}\text { No. of } \\
\text { patients }\end{array}$ & $\begin{array}{l}\% \text { of } \\
\text { patients }\end{array}$ \\
\hline Normal vaginal delivery & 147 & 76.56 \\
\hline Instrumental vaginal delivery & 15 & 07.81 \\
\hline Cut short second stage & 03 & \\
\hline For fetal distress & 09 & \\
\hline For non-bearing down & 03 & \\
\hline Caessarean section & 30 & 15.62 \\
\hline Previous 2 caesarean section & 06 & \\
\hline Failed induction & 08 & \\
\hline Malpresentation & 04 & \\
\hline Fetal distress & 12 & \\
\hline
\end{tabular}

On analysis of neonatal outcome Table 5 demonstrates grossly in terms of gestation age, APGAR score at $1 \& 5$ minutes, birth weight, NICU admission.

The analysis of Table 5 revealed that 53 (27.60\%) fetus had unfavourable APGAR at birth, among these 20 had single tight loop of cord around neck, recovered soon as the cord was clamped and cut.

Among rest 33 foetus 03 had three loops of cord around neck, 07 had two tight loops of cord around neck, in rest 23 fetus loops of cord were present besides that other factors like prematurity (11), severe preeclampsia (06), chorioamnionits (02), antepartum haemorrhage (04) were also present, may be responsible for foetal distress. On analysis of the status of loops of cord around neck 24 fetus had single tight nuchal cord, 8 had tight double nuchal cord and 02 had three tight nuchal cord rest fetuses had loose nuchal cords and slipped easily over the head during delivery.

The fetus with single tight nuchal cord recovered as the cord was clamped and cut.

There were three fresh still birth and two foetus expired in NICU within 12 hours of birth, in foetus with multiple tight nuchal cord. Among 24 fetus with single tight loop of nuchal cord no fresh still births only one intrauterine death. Table $6 \& 7$ demonstrates this clearly.

Table 5: Neonatal outcome.

\begin{tabular}{|c|c|c|}
\hline & $\begin{array}{l}\text { No. of } \\
\text { patients }\end{array}$ & $\begin{array}{l}\% \text { of } \\
\text { patients }\end{array}$ \\
\hline \multicolumn{3}{|l|}{ Period of gestation } \\
\hline$<34 \mathrm{wk}$ & 12 & 06.25 \\
\hline $34-37$ & 50 & 26.04 \\
\hline $38-40$ & 98 & 51.04 \\
\hline $41 \mathrm{wk}$ or more & 32 & 16.66 \\
\hline Fetal weight & $\begin{array}{l}\text { No. of } \\
\text { fetus }\end{array}$ & $\begin{array}{l}\% \text { of } \\
\text { fetus }\end{array}$ \\
\hline$<2.0 \mathrm{~kg}$ & 10 & 5.20 \\
\hline $2.0-2.5 \mathrm{~kg}$ & 49 & 25.52 \\
\hline $2.6-3.5 \mathrm{~kg}$ & 118 & 61.45 \\
\hline $3.6 \mathrm{~kg}$ or more & 15 & 07.82 \\
\hline \multicolumn{3}{|l|}{ Fetal APGAR status } \\
\hline $1 \mathrm{~min}$ favourable & 134 & 69.79 \\
\hline unfavourable & 53 & 27.60 \\
\hline 5 min favourable & 154 & 80.20 \\
\hline unfavourable & 33 & 17.18 \\
\hline $\begin{array}{l}\text { No of fetus admitted } \\
\text { in NICU }\end{array}$ & 26 & 13.54 \\
\hline $\begin{array}{l}\text { No. of fetus with } \\
\text { mother }\end{array}$ & 159 & 82.81 \\
\hline Total no. of IUDs & 07 & 03.64 \\
\hline IUD & 03 & \\
\hline Fresh still birth & 02 & \\
\hline Failed resuscitation & 02 & \\
\hline
\end{tabular}

Table 6: Status of nuchal cord.

\begin{tabular}{|llll|}
\hline $\begin{array}{l}\text { Single } \\
\text { loop }\end{array}$ & $\begin{array}{l}\text { Double } \\
\text { loop }\end{array}$ & $\begin{array}{l}\text { Three } \\
\text { loops }\end{array}$ \\
\hline $\begin{array}{l}\text { No. of patients having } \\
\text { nuchal cord }\end{array}$ & 154 & 33 & 05 \\
\hline $\begin{array}{l}\text { \% of patients having } \\
\text { nuchal cord }\end{array}$ & 80.20 & 17.18 & 2.60 \\
\hline Loose nuchal cord & 130 & 25 & 03 \\
\hline Tight nuchal cord & 24 & 8 & 02 \\
\hline
\end{tabular}


Table 7: Complications due to nuchal cord.

\begin{tabular}{|c|c|c|c|}
\hline & $\begin{array}{l}\text { Labour } \\
\text { complications }\end{array}$ & $\begin{array}{l}\text { Perinatal } \\
\text { complications }\end{array}$ & $\begin{array}{l}\text { Neonatal } \\
\text { death \& } \\
\text { IUD }\end{array}$ \\
\hline $\begin{array}{l}\text { Single loop } \\
\text { of nuchal } \\
\text { cord }\end{array}$ & $\begin{array}{l}10 \text { (4 had tight } \\
\text { loop) }\end{array}$ & $\begin{array}{l}21 \text { (5 had tight } \\
\text { loop) }\end{array}$ & $\begin{array}{l}01 \mathrm{IUD} \\
\text { calcified } \\
\text { placenta }\end{array}$ \\
\hline $\begin{array}{l}\text { Double } \\
\text { loop of } \\
\text { nuchal cord }\end{array}$ & $\begin{array}{l}08 \text { (all tight } \\
\text { loops) }\end{array}$ & $\begin{array}{l}10 \text { (8 had tight } \\
\text { loop) }\end{array}$ & $\begin{array}{l}03 \text { ( } 1 \text { FSB, } \\
\text { and } 02 \\
\text { expired in } \\
12 \text { hours }\end{array}$ \\
\hline $\begin{array}{l}\text { Three loop } \\
\text { of nuchal } \\
\text { cord }\end{array}$ & $\begin{array}{l}03 \text { ( } 2 \text { pts. had } \\
\text { tight loop) }\end{array}$ & $\begin{array}{l}02 \text { (all had } \\
\text { tight loop) }\end{array}$ & $\begin{array}{l}02(1 \mathrm{IUD}, \\
1 \mathrm{FSB}\end{array}$ \\
\hline
\end{tabular}

\section{DISCUSSION}

Umbilical cord provides nutrients and performs gaseous exchange besides support and adherence to the foetus. Birth asphyxia leading to acidosis comprises $20-60 \%$ of perinatal mortality, inclusive of preterm deliveries. ${ }^{1}$ Many a times nuchal cord was held responsible for this birth asphyxia leading to neonatal mortality and morbidity and therefore prenatal ultrasonographic detection of nuchal cord was emphasized. This study is an effort to assess whether ultrasonographic detection of nuchal cord is required or not.

The incidence of nuchal cord in present study was $6.13 \%$ and for single loop it was $4.93 \%$ for double loop $1.05 \%$ and triple loop it was $0.16 \%$. Studies reported prevalence of nuchal cord between 6-37\% and Shui and Eastmen found the incidence of a single loop to be $20.6 \%$, a double loop $2.5 \%$ and a triple loop $0.2 \%$ in 1007 infants at delivery. ${ }^{2}$ Among total 192 patients 34 (17.70\%) patients had tight nuchal cord and $158(82.30 \%)$ had loose nuchal cord, thus the incidence of loose and tight nuchal cord was $5.74 \%$ and $1.24 \%$ over 2753 deliveries les compared to literature ${ }^{4}$ The incidence of labour complications and poor perinatal outcome was associated with $15(44.2 \%)$ of patients of tight nuchal cord as shown in table 7 among which 10 patients had multiple loops. On analysis of patients profile nuchal cord was more common in primiparous patients $(55.4 \%)$ may be because of good tone of anterior abdominal muscles. ${ }^{4}$ Table 2 revealed no undue prolongation of labour because of single nuchal cord but multiple nuchal cord resulted in prolongation of labour. Multiple nuchal cord along with malrotation and malpresentation may be the combined factor or may be multiple cord per se were responsible for that for not allowing full flexion of foetal head.

On analysis of APGAR and neonatal outcome it was found that foetus with unfavourable APGAR at $1^{\text {st }}$ minute had tight nuchal cord and foetus recovered as soon as the cord compression was over on clamping and cutting it. The cyanosis of foetus recovered fully in the observation period with oxygen only. All the foetus admitted in NICU $(13.5 \%)$ had confounding factors like prematurity, intrauterine growth restriction, prolonged leaking per vaginum, thick meconium. No otherwise healthy foetus with nuchal cord stayed in NICU. The pattern of foetal distress was non-specific; the incidence of distress was more in second stage of labour and occurs mainly during contraction with descent of foetal head. Table 7 demonstrates complications in nuchal cords. Labour complications include all prolonged labour, emergency caesarean section, instrumental delivery. Perinatal complications include all unfavourable APGAR at $5 \mathrm{~min}$, NICU admissions.

The diagnosis of nuchal cord by ultrasonography shows that $25-50 \%$ of nuchal cord formed at any one time will resolve prior to delivery and upto $60 \%$ of foetuses have a nuchal cord present at some time during pregnancy. So detection of nuchal cord in early gestation is not of much significance as it may resolve itself. If there is a nuchal cord presentation the onset of labour than it is very unlikely to correct it after wards and if there is no nuchal cord prelabour then one is unlikely to have nuchal cord during delivery as head descends down in the pelvis. During labour it can be suspected by presence of variable decelerations in CTG particularly shouldering effect or clinically can be suspected when there is no descent of foetal head inspite of good uterine contractions and bishop score. By the present study we found that it is the tightness of nuchal cord ${ }^{5}$ and number of nuchal cord ${ }^{6}$ that affects the neonatal outcome. Ultrasonographically it is very difficult to distinguish a loose nuchal cord from tight one, Ranzni et al. described "indent sign" but most of the sonologists are not able to appreciate ${ }^{2}$. Nuchal cord is very common and is usually associated with good outcome. ${ }^{1,3,7}$ Ultrasonographic diagnosis will be helpful if we can assess number of loop and tightness of cord. Intrapartum foetal monitoring is very important and caesarean section should be decided on the evidence of fetal distress only not on the ultrasonographic detection of nuchal cord.

\section{CONCLUSION}

The presence of nuchal cord does not seem to increase the risk of poor neonatal outcome and undue prolongation of labour. Routine ultrasonographic nuchal cord detection is not required and should not alter obstetric management of the patient.

\section{Funding: No funding sources \\ Conflict of interest: None declared}

Ethical approval: The study was approved by the institutional ethics committee

\section{REFERENCES}

1. Narang Y, Vaid NB, Jain S, Suneja K, Faridi MMA, Gupta B. Is nuchal cord justified as a cause of obstetrician anxiety? Arch Gynecol Obstet. 2014 Apr;289(4):795-801. 
2. Peregrine E, O’Brien P, Jauniaux E. Ultrasound detection of nuchal cord prior to labour induction and the risk of caesarean section. Ultrasound Obstet Gynecol. 2005;25:160-4.

3. Gonzalez-Quintero VH, Tolyamat L, Muller AC, Izquierdo L, O'Sullivan MJ, Martin D. Outcomes of pregnancies with sonographically detected nuchal cords remote from delivery. J Ultrasound Med. 2004;23:43-7.

4. Henry E, Andres RL, Christensen RD. Neonatal outcome following tight nuchal cord. J Perinatol 2013;33(3):231-4.

5. Dhar KK, Ray SN, Dhall CI. Significance of nuchal cord. J Indian Med Assoc. 1995:939(12):451-3.
6. Larson JD, Rayburn WF, Crosby S, Thurnau GR. Multiple nuchal cord entanglements and intrapartum complications. Am J Obstet Gynecol. 1995;173(4):1228-31.

7. Ghi T, Emidio DL, Morandi R, Casadio P, PiluG. Nuchal cord entanglement and outcome of labour induction. J Prenat Med. 2007;1(4):57-60.

DOI: $10.5455 / 2320-1770 . i j \mathrm{rcog} 20140908$

Cite this article as: Sangwan V, Sangwan M, Siwach S, Mahendroo R, Kansal R, Lakra P.

Ultrasonographic detection of nuchal cord: required or not. Int J Reprod Contracept Obstet Gynecol 2014;3:507-11. 